\title{
AN ANNOTATED CHECKLIST OF GRASSES (POACEAE) OF NAGPUR AND BHANDARA DISTRICTS OF MAHARASHTRA STATE, INDIA
}

\author{
V J Tiwari ${ }^{1}$ and $\mathbf{P} \mathbf{N}$ Purekar ${ }^{2}$
}

Department of Botany, J M Patel College, Bhandara

Retd. Professor and Head, Department of Botany, Shivaji Science College, Nagpur

vijaysstiwari@gmail.com

Communicated : 19.12.19
Revision : 07.01.2020

Accepted : 25.01.2020
Published: 30.01 .2020

\begin{abstract}
:
The Bhandara and Nagpur district are located in Maharashtra State. This area harbours 153 species of grasses distributed among 64 genera of the family Poaceae. These districts contribute for rich biodiversity of grasses.
\end{abstract}

Key words: - Bhandara, Poaceae and biodiversity

\section{INTRODUCTION:}

Poaceae is the fourth largest family of the flowering plants.It includes about 700-800 genera and 11000 - 13000 species (Clayton and Renvoize 1986). A mention must be made of two illustrated accounts of Indian Grasses inpreindependance era. These are " A Handbook of South Indian Grasses" by Achariyar and Mudliyar (1921) and "Bombay Grasses" by Blatter and McCann (1935). Pioneer work in the field of study of grasses started by Bor (1960), Lisboa (1886); Duthie (1883) and Achariyar and Tadulinga (1921).Grassland occupy nearly 24\% of geographical area of India which are spread across several phytogeographic regions and exhibit a wide range of ecological characteristics (Singh et.al. 1983). The urgent need of assessment of grass cover was felt strongly as early as 1970,s (Dadabghao and Sankarnarayan 1973; Yadava and Singh 1977). Raizda and Jain (1964, 1966) reported grasses of upper Gangetic Plain. Sharma et.al (1996) recorded 373 species belonging to 104 genera of grasses Karthikeyan et.al. (1989) listed 1254 species belonging to 260 genera of grasses. Moulik (1997) wrote a book on Grasses and Bamboos of India.
In Maharashtra, Deshpande and Singh 1986 recorded 397 species belonging to 109 genera of grasses. Potdar et.al. (2012) reported 415 species distributed in 125 genera of grasses.Salunke et.al.(2004)reported a new species of Mnesitheafrom India and Salunke and Potdar (2004) reported Eulaliashrirangii. Potdaret. al. (2005) reported new genus of grasses from Maharashtra State.Salunke et.al. 2002 rediscovered Hubbardiaspecies. Potdar et.al. (2003) reported a new species of Themeda from India. Potdar and Yadav (2011) reported a new variety of Glyphochloafrom Western Ghats of Maharashtra. Patunkar (1980) worked on Grasses of Marathwada region of Maharashtra State.

The history of botanical exploration in the adjoining region of Bhandara and Nagpur districts reveals that Witt (1911 a, b) published "List of fodder grasses found in Berar forest circle of Central Provinces". In addition he took out a beautiful quarto-atlas depicting the habit sketches of 39 grasses. He compiled a list of 80 grass species which he collected from adjoining districts from Amravati, Akola, Buldana, 
Melghat, Yavatmal and Nimardistricts.Nagpur and Bhandara districts was not covered in this work. "A List of Grasses and Sedges of the Nagpur and Telankheri Farms" was prepared by Graham (1913), enumerates 122 grass species. Haines (1916) has enumerated 48 grasses in his "Descriptive List of Trees, Shrubs and Economic Herbs of the Southern Circle of Central Provinces". The area investigated includeWardha, Nagpur, Buldana, Balaghat, Chandrapur, Bilaspur, Durg and Raipur. The exploratory and floristic work in this region has been lately rejunvenated by the sincere efforts of Mirashi (1954); Murty (1972)

Ugemuge (1985) reported 133 species belonging to 66 genus of grasses..Patil (1990) reported 67 species distributed among 38 genus of grasses from adjoining Chandrapur and Gadchiroli districts and Purekar (1985) reported 197 species distributed among 81 genus from adjoining Nagpur district. Tiwari (2013) reported biodiversity of nine species ofEragrostis from Bhandara district. Inspite of such intensive exploration of the plant wealth, there still exist a number of areas which are yet to be explored and hence need urgent attention. The region of Bhandara and Nagpur districts comes under unexplored category therefore the present investigation have been undertaken. The present paper enumerates the species of grasses.

\section{AREA UNDER STUDY:}

Nagpur district lies between 20.35 to 21.44 North Latitude and 78.15 to 79.40 East Longitude., in the plain to which it gives its name at the southern base of the Satpuda Hills. It has an area of 9,892 Sq. $\mathrm{km}$. The average elevation is $354 \mathrm{~m}$. The northern part of Nagpur district is surrounded by Chindwada and Seoni district of Madhya Pradesh and it is Bhandara district on the east. South and West are respectively Chandrapur and Wardha districts. So, some part of the northwest is covered by
Amravati district.There are natural and highly constructed ponds in Nagpur district. Ambajari Lake is the largest in this area. Other natural ponds include Gorewada and Telangkhedilake. The Sonegaon and Gandhisagartalukas are man-made and the historical rulers of the city have created them. Nag river, Piliriver and some nalla are the natural ways of carrying water from the sewage to the city. Nagpur is known as a green city. Nagpur has been recognized as the second most green and cleanest city in India after Chhattisgarh. Nagpur city is rich in natural resources. Along with the agriculture sector, soyabeen, jowar and mineral wealth are rich in district. Nagpur is the largest producer of vegetables and grasses in Nagpur district. Besides, there are large reserves of Manganese in this district. The city of Nagpur, in the middle of the Bay of Bengal and the Indian diaspora that runs away from the Arabian Sea, is in its wet and dry conditions. The city has dry weather for most of the year. During the monsoon of June to September, Nagpur has $1205 \mathrm{~mm}$ of rain. On July 14, 1994, the city had recorded a record rainfall of $304 \mathrm{~mm}$ on the same day. They are equally warm during the summer of March to June. May is the highest temperature in May. November to January is the period of winter. In winter the temperatures below 10 degrees are below. On May 29, 2012, the city recorded 48.6 degrees Celsius and the lowest temperature was 3.9 degree Celsius in 1937. Nagpur district has an average annual rainfall of $1064.1 \mathrm{~mm}$. In Umred, Kuhi and Bhivapur tehsil, the maximum rainfall occurs, whereas in the district of Katol and NarkhedTahsil, less rainfall occurs compared to other tehsils of the district. The Nagpur district is traversed by Nag ,Pench,Kanhan, Aam, Pilli, Kolar, Wardha, Bor, Jam and Vena rivers.

Bhandara district lies between 20॰38' to 21०36' NL and $79^{\circ} 27^{\prime}$ to $80^{\circ} .06^{\prime}$ EL.Theminimum average elevation: $329 \mathrm{~m}$. This district is situated 
on NE side of Maharashtra State. The adjoining districts are Gondia on the eastern side, on the northern side Balaghat district of Madhya Pradesh and on Western side Nagpur district and to the south is Chandrapur district. The district is known as Lake District of Maharashtra. It covers an area of about 3717 sq.km. of which paddy is cultivated in 1718.63 sq.km. It is inhabited by 1254 lakes. The farmers cultivate two crops of paddy. The total forest area of the district is 645.58 sq. $\mathrm{km}$. The district lies in the basin of Wainganga River with its tributaries like Bawanthadi, Chulband, Sur, Godra rivers. The average rainfall is 1250-1500 $\mathrm{mm} /$ year. The mean minimum temperature is $6^{\circ} \mathrm{C}$ and mean maximum temperature is $45^{\circ} \mathrm{C}$.

\section{MATERIAL \& METHODS}

The botanical excursion tours of Nagpur district were conducted by Dr.Purekar from 1975 to 1985 for his doctorate work entitled Grasses of Nagpur District- Taxonomy and Palynology.He was awarded Ph.D and still he is working as aagrostologist in Vidarbha region of Maharashtra State. He reported 188 species distributed among 82 genera.The botanical tours and field visits were conducted in Bhandara district during 2014 to 2019. The herbarium specimens were collected, identified and deposited in the herbarium of Department of Botany, Shivaji Science College, Nagpur and herbarium of $\mathrm{J}$ M Patel College, Bhandara. Mostly the species were collected from paddy fields in Bhandara district and cotton field in Nagpur district and its adjoining areas. Field data as well as other scientific information is noted in the field book.The local flora, monographs of the genus is referred for identification. The material is dissected under the microscope. The species of grasses reported here were collected during 2014 to 2019 covering all habitat types of the region, particularly in protected area of Nagzira Wild
Life Sanctury and Nawegaon Bird Sanctury in Bhandara district and UmredKharangla and Gothangao sanctuary and Pench Tiger Project of Nagpur district. The floristic work was divided into four phases 1. Exploration 2.Identification 3.Literature Study 4.Compilation. Field notes regarding habit, habitat, colour of clums, leaves, spikelets, scent after crushing leaves or panicles, frequency, distribution, associations etc. were recorded. Beside field diary, a register was maintained in which the specimens were listed and numbered serially. In this catalogue tentative identification, locality, date of collection and other relevant information was entered in separate column.

\section{RESULT AND DISCUSSION}

The quantitative survey recorded the presence of 153 species distributed among 63 genera. These species are classified according to Grass Phylogeny Working Group (GPWG 2001). The presentation include name of subfamily, name of tribe, name of genera and number in the bracket indicate the number of species recorded from the districts. The species were collected and their presence is recorded by taking photographs and herbarium sheets.

Subfamily - Bambusoideae; Tribe - Bambuseae :Genera: Bambusa (4), Dendrocalamus (1)

Subfamily- Arundinoideae ; Tribe -Arundineae : Genera - Phragmitis(1)

Subfamily - Centothecoideae; Tribe Thysanolaena - Genera: Thysanolena(1)

Subfamily - Panicoideae;

Tribe: Isachne - Genera: Isachne (1)

Tribe: Arundenelleae - Genera - Arundinella (2)

Tribe: Andropogoneae - Andropogon (1), Apluda (1),Arthraxon(1),Bothriochloa(3), Chionachne(1), 
Chrysopogon(5), Coix (2), Cymbopogon (3), Dichanthium (8), Dimeria (1) Euchlaena (1),Eulatia (2), Eulaliopsis (1), Eremeopogon (2), Hackelochloa (1), Hackelochloa (1),Hemarthria (2), Heteropogon (1), Imperata (1); Iseilema (4), Ischaemum (7), Lophopogon (1),Mnesithea (1)Ophiuros(1),Pogonatherum(1),Psuedanthistiria

(1), Rottboellia (1), Saccharum (2) Schizachyrium (2); Sehima (1); Sorghum(7) Spodiopogon (1)Thelepogon (1)Themeda (3)Vetiveria (1),Zea (1)

Tribe : Paniceae -Alloteropsis (1);Bracharia (9);Cenchrus (3)Digitaria (6);Echinochloa (5)Eriochloa (1);Oplismenus (2);Panicum (6),Paspalidium (2);Paspalum (3);Pennisetum (4);Psuedoraphis (1)Sacciolepis (2);Setaria (6);Stenotaphrum (1)Urochloa (4)

\section{Subfamily - Chloridoieae,}

Tribe - Cynodonteae, Genera :Chloris (4), Cynodon (2)

Tribe: Eragrostideae - Genera - Elusine(1), Eragrostis (10), Leptochloa (1); Sporobolus (4)

\section{CONCLUSIONS:}

Potdar et.al (2012) reported 415 species distributed in 125 genera from Maharashtra.Incomparsion with this finding we conclude that we have reported $36.86 \%$ of grass species and $51.61 \%$ of genera.

\section{ACKNOWLEDGEMENT:}

The authors are thankful to the Principal Dr.VikasDhomne for providing basic infrastructure to carryout present research work.

\section{REFERENCES}

Achariyar K R and C T Mudliyar 1921 A Handbook of some South Indian Grasses. Govt.Press, Madras
Blatter E and McCann C 1935 "The Bombay Grasses", ICAR Publ, Delhi, India

Bor N L 1960 The Grasses of Burma, Ceylon, India and Pakistan. Peragmon Press, London

Clayton W D and Renovize S A 1986 Genera Graminum. Her Majestey Stationary Office, London.

Dabadghao P M and Shankarnarayan K A 1973 The Grass Cover of India. ICAR ,New Delhi.

Duthie J F (1883)A list of grasses of North West India: Indigenous and Cultivated. Roorke.

Deshpande, U. R. and N. P. Singh (1989).Grasses of Maharashtra an annotated inventory.Mittal publications, New Delhi.

GPWG 2001 Phylogeny and Sub familial Classification of Grasses (Poaceae). Annals of Missouri Botanical Garden 88(3): 373-457.

Graham R J D 1913 List of Grasses and Sedges found on the Nagpur AndTelankheri Farms. Govt. Press., Nagpur

Haines H H 1916 Descriptive List of Trees, Shrubs and Economic Herbs of the Southern Circle Central Provinces. Pioneer Press Publ., Allhabad

Karthikeyan, S., S. K. Jain, M. P. Nayar and M. Sanjappa (1989). Florae indicaeEnumeratio :Monocotyledonae, BSI Calkatta.

Mirashi M V 1954 Studies in the Hydrophytes of Nagpur.Jour.Ind.Bot.Soc. 33, 299-308

Moulik, S. (1997).The grasses and bamboos of India.Vol. 1 and 2. Scientific Publisher, Jodhpur.

Murty U R 1972 Taxonomy of Genus Apluda L., Bull. Bot.Survey of India 14, 149.

Patil B M 1990 Floristic and Palynological Investigations in the Monocot Flora of 
the Chandrapur and Gadchiroli districts of Maharashtra State., Ph.D. Thesis, RTM Nagpur University, Nagpur.

Patunkar B N 1980 Grasses of Marathwada, Scientific Publ., Jodhpur, Rajasthan,India

Potdar G G., Salunkhe C B., Yadav S R 2003 A New Species of ThemedaForssk.,(Poaceae) from India. Kew Bulletin 58(1): 243-246

Potdar G G ,Yadav S R 2011 A New Species and a new variety of Glyphochloa (Poaceae) from Western Ghats of India. Kew Bulletin 66(4) : 625-628

Potdar, G. G., C. B. Salunkhe and S. R. Yadav (2012).Grasses of Maharashtra, Shivaji University Publication, Kolhapur.

Potdar G G ,Mahekar P D, Yadav S R 2005 New Generic Records of Grasses of Maharashtra. Jour.Bomb.Nat.Hist.Soc. 102(3): 365

Purekar P N 1985 Grasses of Nagpur District Taxonomy and Palynology, Ph.D. Thesis, RTM Nagpur University, Nagpur

Raizda M B and Jain S K 1964 Grasses of Upper Gangentic Plain. Panicoideae II. Indian For.Rec.5 : 151-226.

Raizda M B and Jain S K 1966 Grasses of Upper Gangetic Plain Pooideae. Indian Forester 92:637-642

Salunkhe C B, Yadav S R, Potdar G G, Gaikwad S P 2004 A New species of
MnesitheaKunth. (Poaceae ) from India. Kew Bulletin 59, 629-631.

Salunkhe C B and Potdar G G 2004 Eulaliashrirangii, a new species of Poaceae from India. Kew Bulletin 59, 625-627.

Salunkhe C B, Yadav S R and Potdar G G (2002) Rediscovery of Grass Hubbardia., Species, 38, pp.12

Sharma, B. D., S. Karthikeyan and N. P. Singh eds. (1996). Flora of Maharashtra state Monocotyledons. BSI Calcutta.

Tiwari V J ( 2013) Biodiversity of Genus Eragrostis Wolf. Of Family Poaceae. UGC Seminar Biodiversity- A Global Need: Kapgate D K., Saha R C (Eds.) Department of Botany, J M Patel College, Bhandara pp.109-113.

Witt D O 1911a "List of Fodder Grasses Found in the Berar Forest Circle of the Central Provinces., Pioneer Press Publ., Allahabad

Witt D O 1911a "List of Fodder Grasses Found in the Berar Forest Circle of the Central Provinces (Quarto Atlas)., Pioneer Press Publ., Allahabad.

Yadava P S and Singh J S 1977 Grasses Vegetation: Its Structure, Function, Utilization and Management. Today and Tomorrow"s Printers and Publishers. 